\title{
Dissemination of potentially pathogenic bacteria into the environment
}

\author{
D. S. Al-Otaibi, A. A. Akbar, H. Drobiova, C. Obuekwe \\ \& E. Al-Saleh \\ Department of Biological Sciences, Faculty of Science, \\ Kuwait University, Kuwait
}

\begin{abstract}
Under certain conditions, untreated wastewater is released into the sea discharging pathogenic microorganisms into the marine environment. Therefore, it is very important to monitor seawater for the presence of such microorganisms and legislate roles and penalties to avoid and prevent the dumping of such hazardous bacteria. The present study demonstrates the occurrence and survival of pathogenic bacteria in seawater samples collected from four locations at ALSabah beach, Kuwait bay. A total of 230 bacteria were isolated and identified by the amplification of 16S rDNA sequences from bacterial pure cultures. Phylogenetic analyses indicated the dominance of three $\gamma$-proteobacteria phylotypes: Enterobacter, Pantoea and Klebseilla. The diversity of the isolated bacteria was examined by restriction fragment length polymorphism (RFLP) analysis of $16 \mathrm{~S}$ rDNA sequences amplified by a polymerase chain reaction (PCR). In addition, the survival of isolated bacteria in seawater was investigated by monitoring their growth and activity. All isolated bacteria exhibited resistance to penicillin and sulphonamides and demonstrated the potential to survive in seawater for 750 hours. This study exemplified the importance of monitoring seawater that may represent a latent source of hazardous bacteria.
\end{abstract}

Keywords: pathogenic, RFLP, PCR, seawater, marine, $16 \mathrm{~S}$ rDNA, phylotypes.

\section{Introduction}

Continuous human activities along the coastal line have resulted in considerable disturbance [15] to marine ecosystems. Kuwait bay is a semi-closed system where the water current is not strong enough to circulate the seawater and due to 
the dumping of untreated wastewaters into the sea [6], pathogenic bacteria, in particular Gram negative bacteria, accumulate in seawater affecting the aquatic ecosystem, especially edible marine organisms such as fish and shrimp [12]. Furthermore, the presence of pathogens in the recreational seawaters exposes bathing individuals to a vast variety of diseases [15]. Bacterial infections caused by Gram negative bacteria, especially those involving vascular access, are considered a major cause of morbidity [13,9], in particular with the prevalence of antibiotic resistant among enterobacterial and non-fermentative Gram negative bacteria, which increases rapidly due to the misuse of antibiotics in healthcare facilities, including haemodialysis units [12]. The emergence of multi resistant Gram negative bacteria is being increasingly recognized [5] and it can develop endogenously through mutation and/or transmission of resistance genes between body bacteria or exogenously through the cross transmission of pathogens between patients, the environment, and/or healthcare workers [5]. The prevalence of pathogenic Gram negative bacteria is influenced by many factors, such as the physiochemical features of the environment $[7,14]$ and the ability of the bacteria to adapt, tolerate and survive various harsh environmental conditions. The survival time of Gram negative organisms on inanimate surfaces was reported to be significantly long [6]. Another reason for the high levels of antimicrobials in the environment is that most of the compounds used in medicine are only partially metabolized by patients and hence mainly released non-metabolized and are then discharged into the hospital sewage system or directly into municipal waste water if used at home. Along with excreta, these compounds flow with municipal wastewater to the sewage treatment plant [10]. They may pass through the sewage system and end up in the environment, mainly in the water compartment [3]. Furthermore, antibacterial substances used for livestock enter the environment when manure is applied to fields. These antibiotics will eventually end up in soil, sediment ground water and seawater. The accumulation of antibacterials in the environment creates selection pressure, especially when antibiotics are present above a certain concentration, which usually result in the selection and spread of resistant bacteria. In addition to antimicrobials, resistant bacteria themselves are excreted by animals and are emitted into sewage or manure and other environmental habitats. Therefore, it is important to monitor the quality of seawater to ensure the absence of hazardous compounds such as heavy metals, pesticides and organisms such as pathogenic bacteria [15].

\section{Material and methods}

\subsection{Sampling and collection}

Seawater samples, in triplicate, were collected from four different locations at AL-Sabah beach, Kuwait bay (Figure 1). Several medical centres are located alongside AL-Sabah beach. Sampling locations were chosen to represent the whole of AL-Sabah beach, which is four kilometres in length. Samples were kept in ice and transported immediately to the laboratory for immediate analysis. 


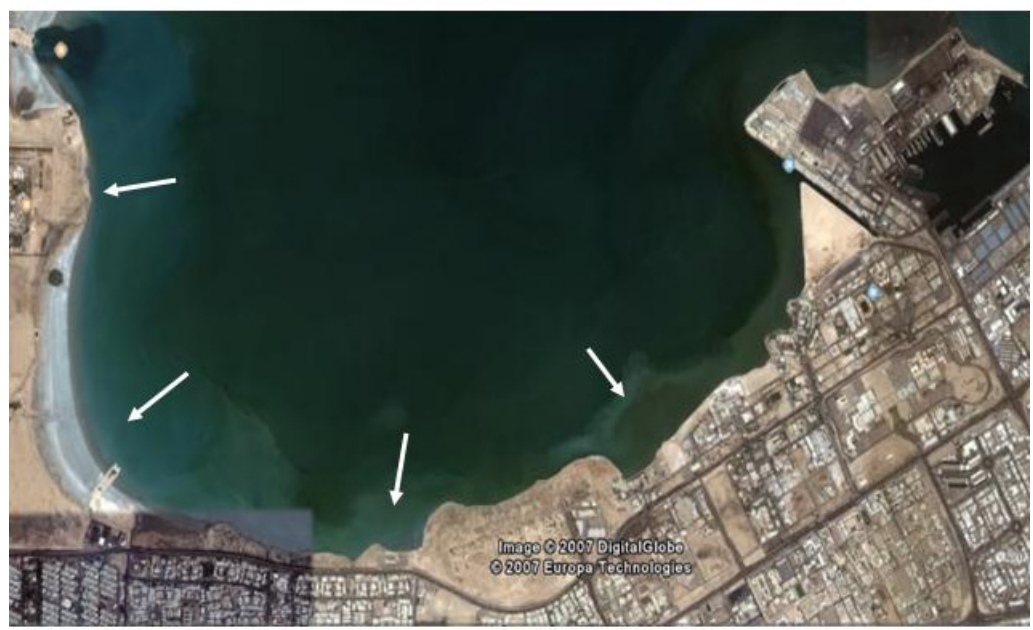

Figure 1: $\quad$ Map of AL-Sabah beach showing the four sampling locations.

\subsection{Isolation, enumeration and identification of bacteria}

Seawater samples from each point of collection were filtered through $0.45 \mu \mathrm{m}$ pore size, $47 \mathrm{~mm}$ diameter sterile cellulose nitrate membrane filters that were then placed on proper media. For the numeration of total heterotrophic bacteria, the method of Reasoner and Gelrech (1985) was adapted. The presence of total Gram negative bacteria was determined by placing filter membranes on eosinmethylene blue (EMB) and MacConkey (MAC) agar. Plates were incubated at $25^{\circ} \mathrm{C}$ for 24 to 48 hours. Growing colonies were counted and pure cultures were isolated. Bacteria were identified using $16 \mathrm{~S}$ rDNA sequencing protocol. For this purpose, genomic DNA was purified from pure bacterial cultures using the Wizard Genomic DNA purification kit (Promega), 16S DNA sequences were amplified from extracted DNA using primers 27F (AGAGTTTGAT CACTGGCTCAG) and 1492R (ACGGCTTACCTTGTTACGACTT) [9]. All reactions were carried out in $25 \mu$ volumes, containing $12.5 \mathrm{pmol}$ of each primer, $200 \mu \mathrm{M}$ of each deoxyribonucleoside triphosphate, $2.5 \mu \mathrm{l}$ of 10x PCR buffer (100mM Tris-HCL, $15 \mathrm{Mm} \mathrm{MgCl} 2,500 \mathrm{mM} \mathrm{KCl} ; \mathrm{pH} 8.3)$ and $0.5 \mathrm{U}$ of Taq DNA polymerase (ABI), increased to $25 \mu \mathrm{l}$ with sterile water. PCR was preformed in a thermocycler (ABI) with the following thermocycling programme: 5 minutes denaturation at $95^{\circ} \mathrm{C}$, followed by 30 cycles of 1 minute denaturation at $95^{\circ} \mathrm{C}, 1$ minute annealing at $55^{\circ} \mathrm{C}, 1$ minute extension at $72^{\circ} \mathrm{C}$, and a final extension step of 5 minutes at $72^{\circ} \mathrm{C}$. The PCR product was visualized by electrophoresis in $2 \%(\mathrm{wt} / \mathrm{vol})$ agarose gels and with ethidium bromide $(0.5 \mu \mathrm{g} / \mathrm{ml})$ staining, then PCR products were used as templates in dye terminator cycle sequencing reactions (ABI PRISM dye terminator cycle sequencing kit). The $16 \mathrm{~S}$ rDNA sequences obtained were run against the databases using the basic alignment search tool (BLAST) and were compared with sequences obtained from the Ribosomal Database Project (RDP), release 9.0. Sequences 
were assigned to recognized representative of the main eubacterial lineages based on the affiliation of the nearest-neighbour sequences from the RDP. Sequences were aligned using CLC Bio software (version 4.0) and phylogenetic trees were created using the neighbour-joining method with bootstrapping.

\subsection{Determination of bacterial growth}

Bacterial survival in seawater was determined by determining the optical density/absorbance $(600 \mathrm{~nm})$ of suspended bacteria in seawater. For this purpose, seawater $(49 \mathrm{ml})$ was transferred to sterile flasks and $1 \mathrm{ml}$ of overnight bacterial suspension (OD $=1$ at $\lambda 600 \mathrm{~nm})$ was added. Flasks were incubated shaking at $25^{\circ} \mathrm{C}$. The absorbance $(\lambda 600 \mathrm{~nm})$ of bacterial suspensions was taken at time intervals. Changes in absorbance were used as an indicator for bacterial survival in seawater.

\subsection{Determination of bacterial respiration}

Bacterial respiration was used as an indicator for bacterial viability and survival. The amounts of carbon dioxide evolved were measured using a Micro-oxymax respirometer (Columbus instruments, USA). The reaction bottles contained seawater $(49 \mathrm{ml})$ and $1 \mathrm{ml}$ of overnight bacterial suspension $(O D=1$ at $\lambda$ $600 \mathrm{~nm})$. The reaction bottles were incubated shaking at $25^{\circ} \mathrm{C}$. The amount of carbon dioxide evolved was plotted against time and the rate of carbon dioxide evolution was calculated and used as an indication for bacterial survival.

\subsection{Determination of bacterial antibiotic sensitivity profile}

Pure cultures of isolated bacteria were used for antibiotic sensitivity testing, which was determined by a ViteKII (bioMe'rieux), following the manufacturers instructions. Resistance to antibiotics was considered as an indicator for the hazardous nature of bacteria [11].

\subsection{Detection of sulphonamides resistance genes}

The Guerra et al. [8] method was followed. A PCR was carried out with two sets of oligonucleotide primers, F and R. The Sul1 gene sequences in genomic DNA were amplified. All reactions were carried out in $25 \mu$ l volumes, containing 12.5 pmol of each primer, $200 \mu \mathrm{M}$ of each deoxyribonucleoside triphosphate, $2.5 \mu \mathrm{l}$ of 10x PCR buffer (100mM Tris-HCL, 15Mm MgCl2, $500 \mathrm{mM} \mathrm{KCl}$; pH 8.3) and $0.5 \mathrm{U}$ of Taq DNA polymerase (ABI), increased to $25 \mu \mathrm{l}$ with sterile water. A PCR was preformed in a thermocycler (ABI) with the following thermocycling programme: 5 minutes denaturation at $95^{\circ} \mathrm{C}$, followed by 30 cycles of 1 minute denaturation at $95^{\circ} \mathrm{C}, 1$ minute annealing at $55^{\circ} \mathrm{C}, 1$ minute extension at $72^{\circ} \mathrm{C}$, and a final extension step of 5 minutes at $72^{\circ} \mathrm{C}$. PCR products were visualized by electrophoresis in $2 \%(\mathrm{wt} / \mathrm{vol})$ agarose gels and with ethidium bromide $(0.5 \mu \mathrm{g} / \mathrm{ml})$ staining then, PCR products were sequenced using dye terminator cycle sequencing reactions (ABI PRISM dye terminator cycle sequencing kit). 


\section{Results and discussion}

The identity of isolated bacteria (Table 1) confirmed the contamination of ALSabah beach with bacteria that are known to inhabit the human digestive tract [1]. Analysis of the RFLP-16S rDNA digestion patterns of the three predominant isolated bacteria (Enterobacter, Pantoea and Klebsiella) demonstrated the presence of different clusters (phylotypes) for each genus [2]. For example, isolated Enterobacter strains were grouped in thirteen main clusters/phylotypes with similarity values ranging from 19.4 to $99.4 \%$ (Figure 2). Each cluster probably represents a strain with different characteristics and pathogenicity. The presence of different strains for a genus (Enterobacter, Pantoea and Klebsiella) reflects the diversity of the bacteria on AL-Sabah beach. Further characterization of isolated bacteria showed their resistance to penicillins and sulphonamides (Figure 3), which may indicate the possibility of horizontal transfer of antibiotic resistance genes among bacteria on AL-Sabah beach. Acquired antibiotic resistance in bacteria is generally mediated by plasmids that are transmitted to the next generation and among different bacterial populations [6].

In addition, the survival of isolated bacteria in seawater was investigated by monitoring the activity (respiration) and growth (absorbance - optical density). Tested bacteria demonstrated different levels of tolerance to seawater. For example, the activity of Enterobacter $s p-174$ was not affected during the period of the experiment while its growth showed two distinct phases, probably due to adaptation to the seawater environment, resulting in the steady inhibition of the bacterium growth after $220 \mathrm{hrs}$ of incubation (Figure 4). Enterobacteria, such as the enterobacter species, have an advantage in terms of persistence and multiplication due to their tolerance to various environmental factors, such as an alkaline $\mathrm{pH}$, increased temperature and sodium chloride concentrations [3].

Table 1: $\quad$ Gram negative bacteria isolated from AL-Sabah beach samples in Kuwait bay.

\begin{tabular}{|c|c|}
\hline Bacteria & Number of isolated strains \\
\hline \hline Enterobacter $s p$. & 23 \\
\hline Pantoea agglomerans & 5 \\
\hline Klebsiella $s p$. & 14 \\
\hline Citrobacter freundii & 3 \\
\hline Shigella flexneri & 1 \\
\hline Acinetobacter radioresistens & 1 \\
\hline \hline Serratia marcescencs & 1 \\
\hline \hline Shewanella sp. & 1 \\
\hline Exiguobacterium marinum & 2 \\
\hline Halomonas $s p$. & 2 \\
\hline
\end{tabular}


156 Environmental Health Risk V

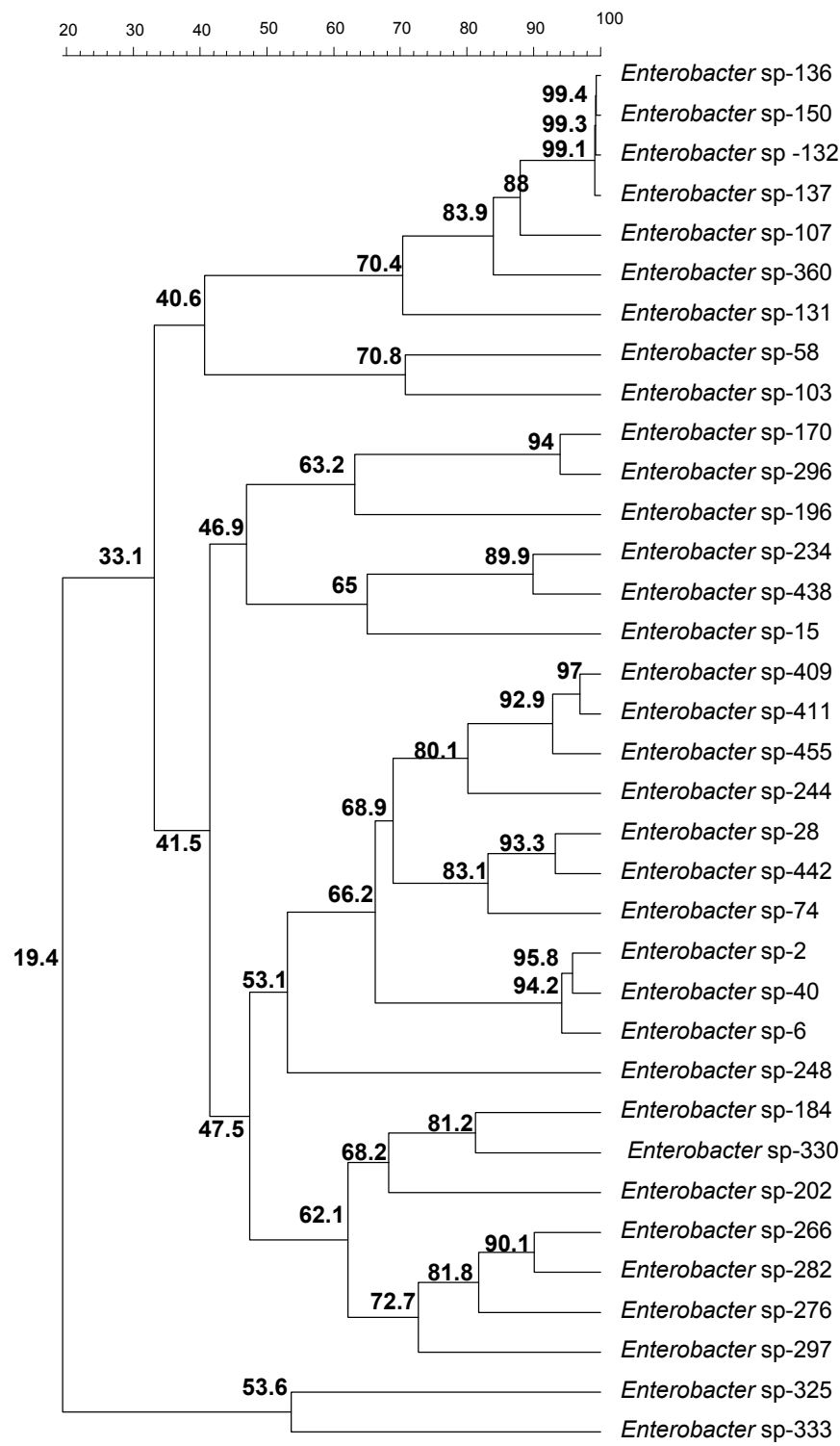

Figure 2: Dendrogram constructed by UPGMA cluster analysis of similarity coefficients derived from RFLP analysis of $16 \mathrm{~S}$ rDNA of Enterobacter species obtained with Bst UI. The levels of linkage representing the Pearson correlation/UPGMA are expressed as percentages. Enterobacter strains were isolated from four coastal locations at AL-Sabah beach. 


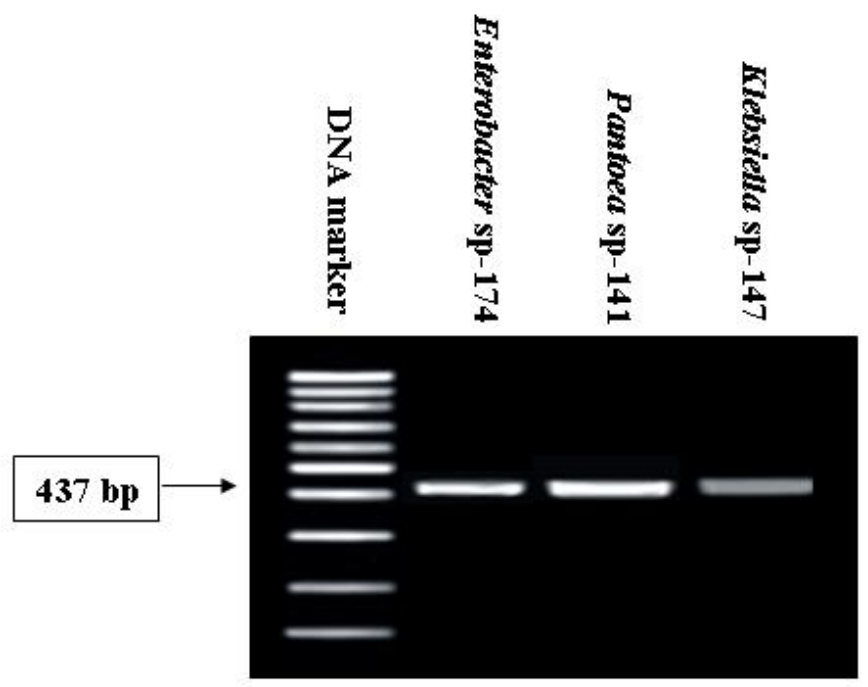

Figure 3: $\quad$ Photograph of $2 \%(\mathrm{w} / \mathrm{v})$ agarose gel showing amplified products of sul1 for Enterobacter sp-174, Pantoea sp-141 and Klebsiella $\mathrm{sp}-147$ formed from preparations of DNA isolated from bacteria pure cultures.

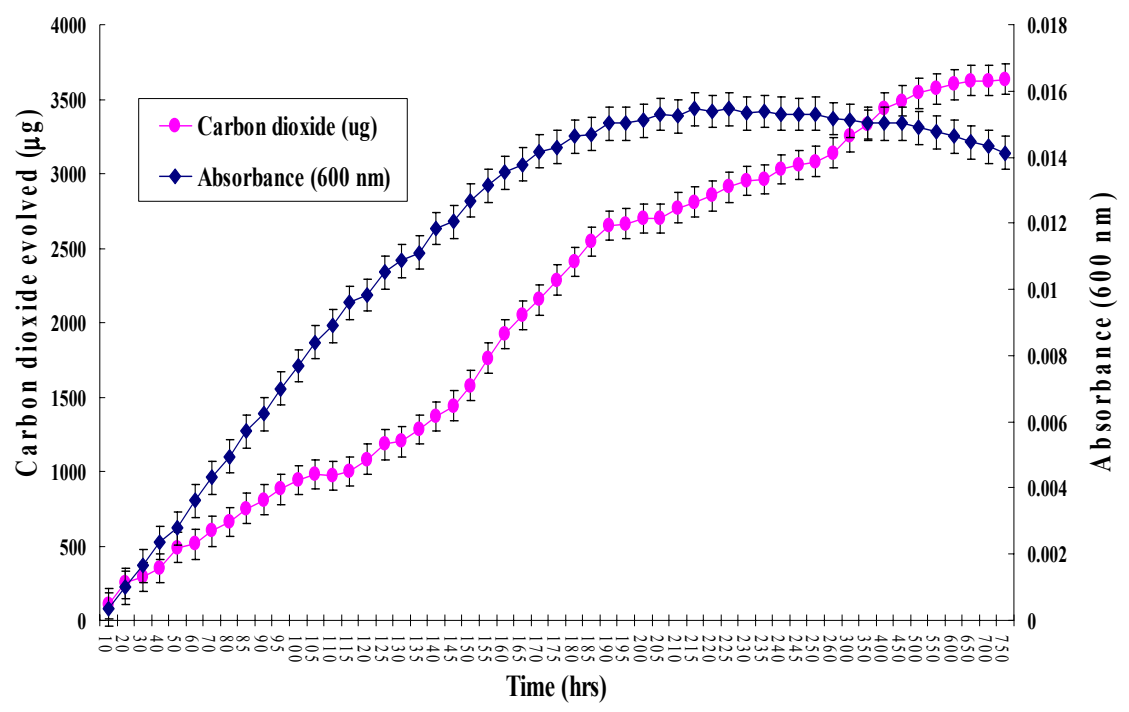

Figure 4: $\quad$ Survival of Enterobacter sp-174 I in seawater samples. 


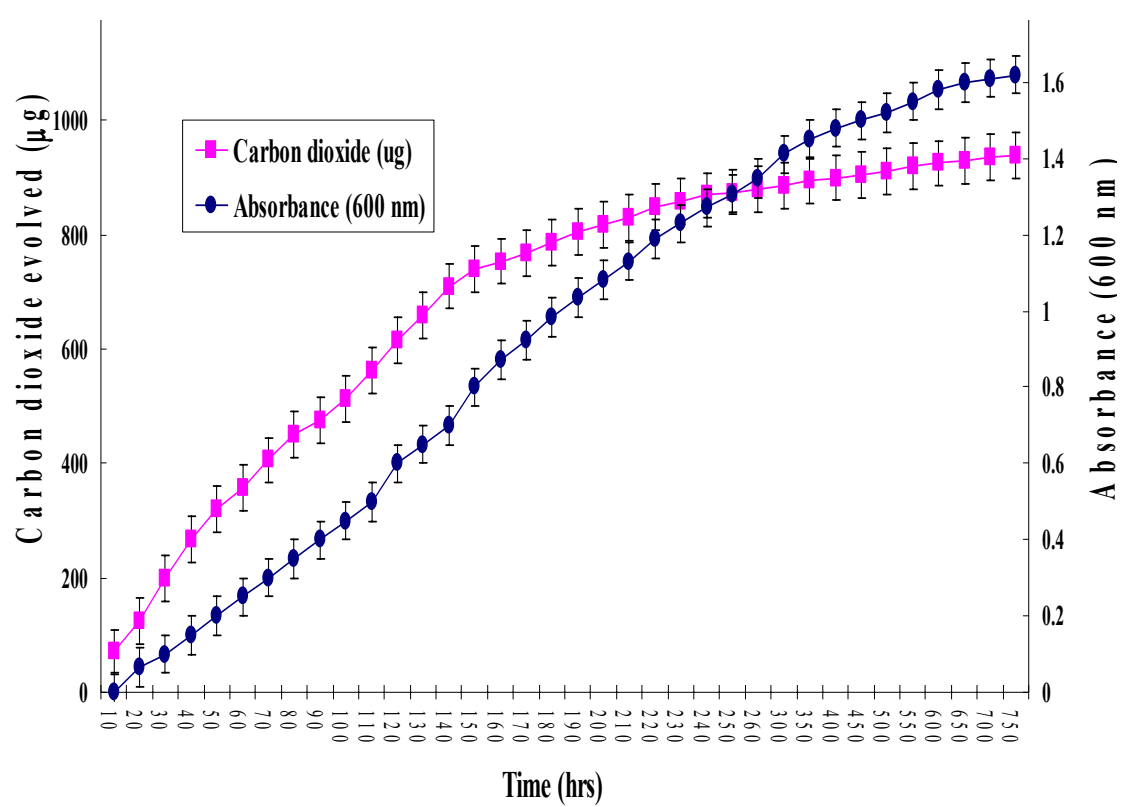

Figure 5: $\quad$ Survival of Pantoea agglomerans-141 in seawater samples.

However, Pantoea agglomerans-141 showed a different pattern of survival in seawater. A gradual increase in the activity and growth of Pantoea agglomerans141 was noticed, which probably indicated the higher potential of this bacterium to adapt and survive in seawater compared to Enterobacter sp-174 (Figure 5). In conclusion, seawater samples from AL-Sabah beach were contaminated with potentially pathogenic bacteria able to survive for at least $750 \mathrm{hrs}$ in seawater. This represents hazards to humans and sea organisms. Thus, proper measures must be taken to prevent the dumping/release of such bacteria into seawaters.

\section{Acknowledgements}

This project was funded by Grant YS04/05. Many thanks to the Biotechnology Center (BTC), College of Science - Kuwait University for the help with the sequencing. Also, the assistance of the people in lab 108 is highly appreciated.

\section{References}

[1] Alexander, L. M., Heaven, A., Tennant, A. and Morris, R., Symptomatology of children in contact in seawater contaminated with sewage. J Epidemiol Community Health, 46, pp. 340-344, 1992.

[2] Al-Saleh E. and Obuekwe C., Int Biorem Biodeg, Inhibition of hydrocarbon bioremediation by lead in a crude oil-contaminated soil, 56, pp. 1-7, 2005. 
[3] Bjorkman, J.M. Nagaev, I. and Breg, O. G. Effects of environment on compensatory mutations to ameliorate costs of antibiotic resistance. Science, 287, pp. 1479-82, 2000.

[4] Cheunk, W. H. S., Cang, K. C. K. and Hung, P. P. S., Health effects of beach water pollution in Hong Kong. Epidemiol Infect, 105, pp. 139-162, 1990.

[5] D'agata, E. M. C., Venkataramanm L., Degirolami, P. and Samore, M., Molecular epidemiology of Ceftazidime-resistant Gram-negative Bacilli on inanimate surfaces and their role in cross-transmission during nonoutbreak periods. J Clin Microbiol, 37(9), pp. 3065-3067, 1999.

[6] Davison, J., Genetic exchange between bacteria in the environment. Plasmid, 42, pp. 73-91, 1999.

[7] Epstein, P. R., Ford, T. E. and Colwell, R. R., Mar Ecosys. Lance, 342, pp. 1216-1219, 1993.

[8] Guerra, B., Soto. S., Arguelles, M., and Mendiza, M., Multidrug Resistance is Mediated by Large Plasmids Carrying a class 1 integron in the emergent Salmonella enterica serotype [4,5,12:i:2]. Antimicrob Agents Chemoth, 45(4), pp. 1305-1308, 2001.

[9] Jackson, B.M., Beck-Sague, C. M., Bland, L. A., Arduino, M. J., Meyer, L. and Javris, W. R., Outbreak of pyrogenic reactions and Gram-negative bacteremia in haemodialysis center. American J Nephrol, 14, pp. 85-89, 1994.

[10] Kummerer, K., Resistance in the environment. J Antimicrob Chemoth, 54, pp. 311-320, 2004.

[11] Sessink, P. J. and Bos, R. P., Drugs hazardous to healthcare workers. Eval Meth Monitor Occup Expos Cytostat Drugs, 20(4), pp, 347-359, 1999.

[12] Tokars, J. I., Infections due to antimicrobial-resistant pathogens in the dialysis unit. Blood Purif, 18, pp. 355-360, 2000.

[13] Vanholder, R., Vanhaecke, E. and Ringoir, S., Waterborn Pseudomonas septicemia. ASAIO Trans, 36, pp. M215-M216, 1990.

[14] West, P.A., The human pathogenic vibrios. A Public Health Update with Environmental perspectives. Epidemiol Infect, 103, pp. 1-34, 1989.

[15] Al-Yamani, F. Bishop, J., Ramathan E., Al Hussaini, M. and Ghadban, A., (eds). Oceanographic Atlas of Kuwait, Kuwait Institute for scientific research: Kuwait, 2004. 